\title{
Differential escape from parasites by two competing introduced crabs
}

\author{
April M. H. Blakeslee ${ }^{1, *}$, Carolyn L. Keogh ${ }^{2}$, James E. Byers ${ }^{3}$, Armand M. Kuris ${ }^{4}$ \\ Kevin D. Lafferty ${ }^{5}$, Mark E. Torchin ${ }^{6}$
}

\author{
${ }^{1}$ Marine Invasions Lab, Smithsonian Environmental Research Center, 647 Contees Wharf Road, Edgewater, \\ Maryland 21037, USA \\ ${ }^{2}$ Environmental Studies Department, Emory University, Atlanta, Georgia 30322, USA \\ ${ }^{3}$ Odum School of Ecology, University of Georgia, Athens, Georgia 30602, USA \\ ${ }^{4}$ Department of Ecology, Evolution and Marine Biology, and Marine Science Institute, University of California, \\ Santa Barbara, California 93106, USA \\ ${ }^{5}$ Western Ecological Research Center, US Geological Survey, Marine Science Institute, University of California, \\ Santa Barbara, California 93106, USA \\ ${ }^{6}$ Smithsonian Tropical Research Institute, Apartado 0843-03092 Balboa, Ancon, Republic of Panama
}

\begin{abstract}
Although introduced species often interact with one another in their novel communities, the role of parasites in these interactions remains less clear. We examined parasite richness and prevalence in 2 shorecrab species with different invasion histories and residency times in an introduced region where their distributions overlap broadly. On the northeastern coast of the USA, the Asian shorecrab Hemigrapsus sanguineus was discovered 20 yr ago, while the European green crab Carcinus maenas has been established for over $200 \mathrm{yr}$. We used literature and field surveys to evaluate parasitism in both crabs in their native and introduced ranges. We found only 1 parasite species infecting $H$. sanguineus on the US East Coast compared to 6 species in its native range, while $C$. maenas was host to 3 parasite species on the East Coast compared to 10 in its native range. The prevalence of parasite infection was also lower for both crabs in the introduced range compared to their native ranges; however, the difference was almost twice as much for $H$. sanguineus as for $C$. maenas. There are several explanations that could contribute to $C$. maenas' greater parasite diversity than that of $H$. sanguineus on the US East Coast, including differences in susceptibility, time since introduction, manner of introduction (vector), distance from native range, taxonomic isolation, and the potential for parasite identification bias. Our study underscores not just that non-native species lose parasites upon introduction, but that they may do so differentially, with ramifications for their direct interactions and with potential community-level influences.
\end{abstract}

KEY WORDS: Carcinus maenas · Hemigrapsus sanguineus $\cdot$ Introduced species · Parasite richness · Parasite prevalence

- Resale or republication not permitted without written consent of the publisher

\section{INTRODUCTION}

Throughout seafaring history, ships traveling from port to port have facilitated the introduction of species to foreign habitats (e.g. Carlton \& Geller 1993). Successful invaders often benefit from a lack of, or a reduction in, many of the ecological and/or physical constraints which restrict the invader's density, range, and ecological niche in its native territory (e.g. Min- chella \& Scott 1991, Cohen \& Carlton 1998, Ruiz et al. 2000, Torchin et al. 2005), often resulting in enhanced fitness in the new habitat (e.g. Torchin et al. 2003, Sax et al. 2007). In particular, invading species often leave behind predators and parasites in their native regions (Torchin \& Mitchell 2004).

While several studies have compared parasitism of a single species in native versus introduced range(s) (see review in Torchin \& Mitchell 2004), fewer have 
evaluated multiple introduced species within a single region and how escape from enemies such as parasites could influence interactions between or among species that inhabit similar niches (Settle \& Wilson 1990). A notable single species example of parasite escape is the European green crab Carcinus maenas. Since its appearance on the North American East Coast 200 yr ago (Carlton \& Cohen 2003), the crab has spread from Virginia, USA, to Atlantic Canada (Delaney et al. 2008), and it has had both ecologically and economically significant impacts on the native biota of its introduced range (Glude 1955, Ropes 1968, Lohrer \& Whitlatch 2002). In its native Europe, parasitism (specifically by parasitic castrators) is common and negatively correlated with the average body size and biomass of crab populations, while in North America, crabs are unparasitized by castrators, are larger, and are more abundant than in Europe, suggesting a fitness benefit from reduced parasitism (Torchin et al. 2001).

A more recent invader to the northeastern USA, Hemigrapsus sanguineus (Asian shorecrab), is now vying with Carcinus maenas as the most abundant US East Coast shorecrab. H. sanguineus was first observed in Long Island Sound, USA, in 1988 (McDermott 1998) and has since increased its range southwards to North Carolina and northwards into southern Maine (Delaney et al. 2008), monopolizing the majority of rocky intertidal habitats within this region (Kraemer et al. 2007). In much of its new range, $H$. sanguineus has displaced $C$. maenas as the most abundant rocky intertidal crab (Ahl \& Moss 1999, Lohrer \& Whitlatch 2002, Griffen \& Byers 2009), occurring at twice the average density (and up to 10 times the density) of $C$. maenas in the intertidal zone (Griffen \& Byers 2009). While $H$. sanguineus and $C$. maenas co-occur in the Gulf of Maine, the southern densities of C. maenas have declined precipitously due, at least in part, to strong negative interspecific interactions between the crabs (Tyrrell \& Harris 1999, Lohrer \& Whitlatch 2002, Griffen et al. 2008, Griffen \& Byers 2009). On the whole, the introduction of $H$. sanguineus has resulted in a substantial shift in the most common New England intertidal shorecrab over the last couple of decades (e.g. Jensen et al. 2002, Lohrer \& Whitlatch 2002, Tyrrell et al. 2006, Kraemer et al. 2007, Griffen et al. 2008, Griffen \& Byers 2009).

While parasites of Carcinus maenas in native and introduced populations have been evaluated in detail (Torchin et al. 2001, Kuris et al. 2005), parasites of Hemigrapsus sanguineus in its newly invaded North American range have yet to be adequately quantified. We therefore sought to quantify parasitism of $H$. sanguineus where it overlaps with $C$. maenas on the US East Coast and also within its native Asian range using successful techniques employed for C. maenas (Torchin et al. 2001, J.E.B unpubl.). We then compared these results to a combination of published, unpublished, and new parasite data for C. maenas in its introduced and native ranges.

\section{MATERIALS AND METHODS}

To obtain parasite richness and prevalence data for Carcinus maenas (Brachyura: Portunoidea: Portunidae), we used the following records: (1) field and literature data from Torchin et al. (2001) and Kuris et al. (2005) for Europe and the US East Coast; (2) previously unpublished European field data (sites in Spain, Portugal, France, Great Britain, Norway, Sweden, and Netherlands) collected by M.E.T., A.M.K., and K.D.L. in 2000; and (3) 2 new East Coast field sites (Appledore Island, Maine and Adams Point, New Hampshire) collected in 2007 (Table 1). Parasites were identified by A.M.H.B. and C.L.K. and confirmed by A.M.K. and/or M.E.T. Sites used in analyses were chosen over a broad geographic scale to encompass a large proportion of the crab's range on both Atlantic coasts (Fig. 1, Table 2) and included both estuarine and coastal locations. Adult crabs were hand-collected in the intertidal zone with baited traps.

For Hemigrapsus sanguineus (Brachyura: Grapsoidea: Varunidae), native parasite diversity has been only partially documented in the literature (Torchin et al. 2001, McDermott 2007), and nothing has yet been compiled to show overall parasite richness in the crab in either the native or introduced populations. In its native Asian range, some information on individual parasites has been compiled (e.g. Otagaki 1958, Bridgman 1971, Yamaguchi et al. 1984, Takahashi \& Matsuura 1994, Kifune \& Koga 1999; see Table 1). We used these literature records as well as previously unpublished field data collected by A.M.K. and K.D.L. in 1995 from Japan to establish parasite species richness and prevalence in native $H$. sanguineus populations. For this latter work, H. sanguineus crabs were collected from 7 sites throughout much of Japan (Fig. 1, Table 2). In its introduced US East Coast range, little is known about parasite diversity of $H$. sanguineus, with the exception of 2 studies: Torchin et al. (2001) in Ocean City, MD, where 27 crabs were investigated and 1 larval nematode was found, and McDermott (2007) in Cape May, NJ, where 250 crabs were investigated and no parasites were found. Therefore, in the summer and fall of 2007 we collected and dissected an average of 20 crabs site ${ }^{-1}$ from 7 geographically spaced sites (Fig. 1, Table 2). Crabs used in analyses were all adults and were hand-collected in the intertidal zone from coastal sites. 
Table 1. Total parasite species richness in Carcinus maenas and Hemigrapsus sanguineus in native and introduced regions. Data include literature and field records from sources indicated in the citation column

\begin{tabular}{|c|c|c|c|}
\hline Parasite & Type of parasite & Locations & Source \\
\hline \multicolumn{4}{|l|}{ Carcinus maenas } \\
\hline \multicolumn{4}{|l|}{ Native } \\
\hline Profillicollis botulus & Acanthocephalan & Scotland & $\begin{array}{l}\text { Thompson (1985), Torchin et al. } \\
\text { (2001) [as Polymorphus sp.] }\end{array}$ \\
\hline Trypanorhynch cestode & Cestode & Spain & $\begin{array}{l}\text { Kuris et al. (2005), Torchin et al. } \\
\text { (2001) }\end{array}$ \\
\hline Tetraphyllid cestode & Cestode & Spain, Portugal & $\begin{array}{l}\text { Kuris et al. (2005), M.E.T., A.M.K., } \\
\text { K.D.L. (unpubl.) }\end{array}$ \\
\hline Portunion maenadis & Isopod & $\begin{array}{l}\text { England, Denmark, } \\
\text { France, Portugal, } \\
\text { Sweden }\end{array}$ & $\begin{array}{l}\text { Bourdon (1960, 1963, 1964), } \\
\text { Crothers (1968), Rasmussen } \\
\text { (1973), Torchin et al. (2001) }\end{array}$ \\
\hline Thelohania maenadis & Microsporan & Spain & $\begin{array}{l}\text { Kuris et al. (2005), M.E.T., A.M.K., } \\
\text { K.D.L. (unpubl.) }\end{array}$ \\
\hline Abelspora portulacensis & Microsporan & Spain & $\begin{array}{l}\text { Kuris et al. (2005), M.E.T., A.M.K., } \\
\text { K.D.L. (unpubl.) }\end{array}$ \\
\hline Carcinonemertes carcinophila & Nemertean & $\begin{array}{l}\text { Netherlands, Belgium, } \\
\text { England, France, } \\
\text { Scotland }\end{array}$ & $\begin{array}{l}\text { Humes (1942), Crothers (1968), } \\
\text { Comely \& Ansell (1989), Torchin et al. } \\
\text { (2001) (as Carcinonemertes sp.) }\end{array}$ \\
\hline Sacculina carcini & Rhizocephalan & $\begin{array}{l}\text { England, Scotland, } \\
\text { Wales, Ireland, } \\
\text { France, Spain, } \\
\text { Sweden, Denmark }\end{array}$ & $\begin{array}{l}\text { Bourdon (1960, 1963), Crothers (1968), } \\
\text { Rasmussen (1973), Minchin (1997), } \\
\text { Mathieson et al. (1998), Torchin et al. } \\
\text { (2001) }\end{array}$ \\
\hline Microphallus similis & Trematode & $\begin{array}{l}\text { England, Wales, } \\
\text { France, Netherlands, } \\
\text { Norway, Portugal, } \\
\text { Spain, Sweden }\end{array}$ & Crothers (1968), Torchin et al. (2001) \\
\hline Microphallus primas & Trematode & Portugal & Castilho \& Barandela (1990) \\
\hline \multicolumn{4}{|l|}{ Introduced } \\
\hline Profillicollis botulus & Acanthocephalan & $\begin{array}{l}\text { Eastern Canada, Maine, } \\
\text { New Hampshire, } \\
\text { Massachusetts }\end{array}$ & $\begin{array}{l}\text { Brattey et al. (1985), Torchin et al. } \\
\text { (2001) (as Polymorphus sp.), present } \\
\text { study }\end{array}$ \\
\hline Unidentified larval nematode $^{a}$ & Nematode & $\begin{array}{l}\text { Maine, New Hampshire, } \\
\text { Maryland }\end{array}$ & Torchin et al. (2001), present study \\
\hline Microphallus similis & Trematode & $\begin{array}{l}\text { Eastern Canada, Maine, } \\
\text { New Hampshire, Massa- } \\
\text { chusetts, Rhode Island, } \\
\text { Connecticut }\end{array}$ & $\begin{array}{l}\text { Stunkard (1956), Brattey et al. (1985), } \\
\text { Torchin et al. (2001), present study }\end{array}$ \\
\hline \multicolumn{4}{|l|}{ Hemigrapsus sanguineus } \\
\hline \multicolumn{4}{|l|}{ Native } \\
\hline Unidentified microsporan & Microsporan & Japan & Present study \\
\hline Polyascus (=Sacculina) polygenea & Rhizocephalan & Japan, Russia & $\begin{array}{l}\text { Yamaguchi et al. (1984), Korn et al. } \\
(2000,2004), \text { Isaeva et al. (2001, 2005), } \\
\text { present study }\end{array}$ \\
\hline Sacculina senta & Rhizocephalan & Japan & $\begin{array}{l}\text { Takahashi \& Matsuura (1994), Lützen \& } \\
\text { Takahashi (1997) }\end{array}$ \\
\hline Maritrema setoensis & Trematode & Japan & Bridgman (1971), present study \\
\hline Microphalloides japonicus & Trematode & Japan & Kifune \& Koga (1999), present study \\
\hline $\begin{array}{l}\text { Macrophallus (=Probolocoryphe) } \\
\text { asadai }\end{array}$ & Trematode & Japan & Otagaki (1958), present study \\
\hline \multicolumn{4}{|l|}{ Introduced } \\
\hline Unidentified larval nematode $\mathrm{a}^{\mathrm{a}}$ & Nematode & $\begin{array}{l}\text { Connecticut, New York, } \\
\text { Delaware, Maryland }\end{array}$ & Torchin et al. (2001), present study \\
\hline
\end{tabular}




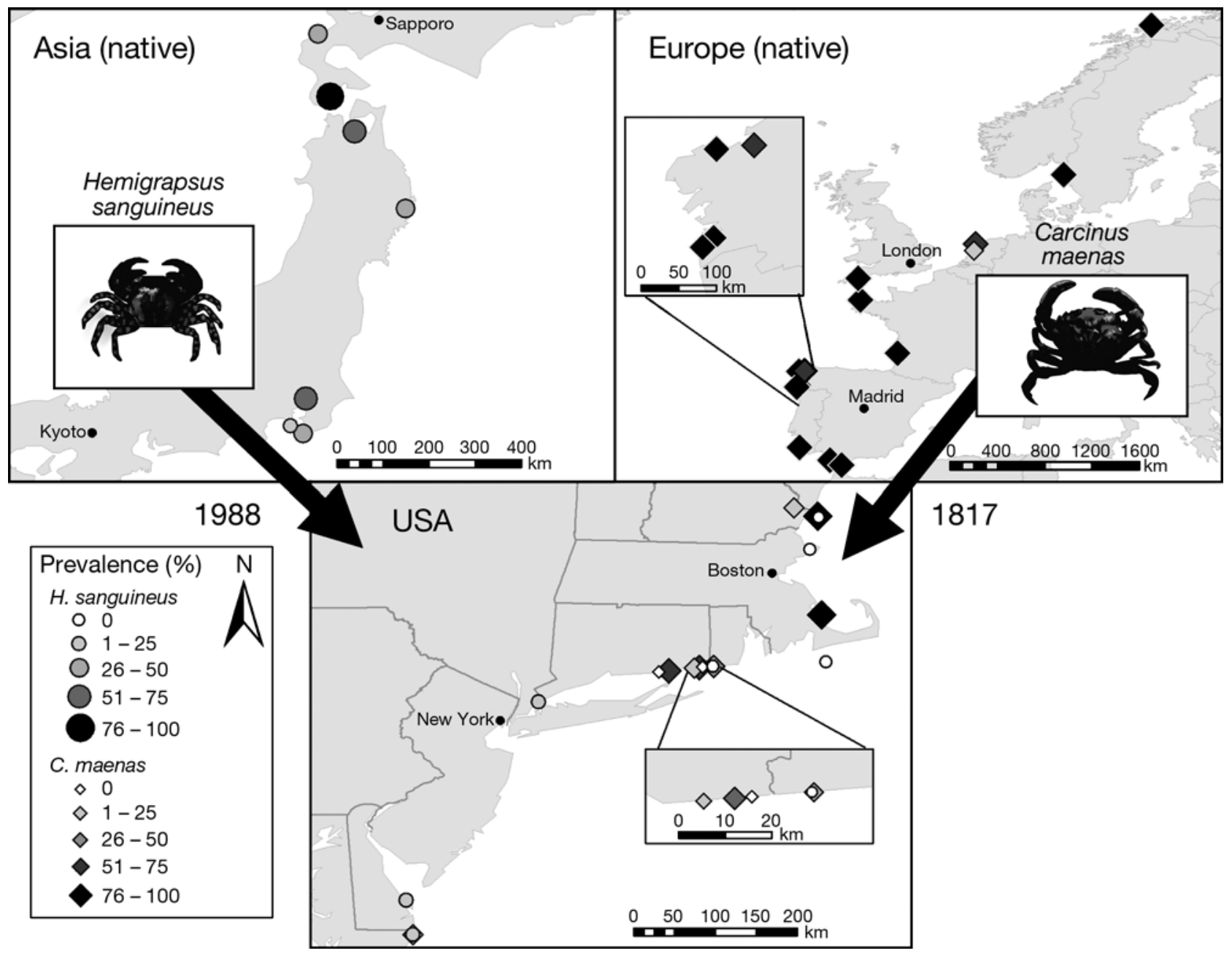

Fig. 1. Hemigrapsus sanguineus and Carcinus maenas. Maps, prevalence, and invasion history information. Circles represent sample sites for $H$. sanguineus in its native Asian and introduced US East Coast populations; diamonds represent sample sites for C. maenas in its native European and introduced US East Coast populations. Circles and diamonds are relatively sized and colored on a gradient of white to black depending on parasite infection prevalence (\%) at each sample site. Dates are the accepted years of introduction for both crab species to the US East Coast

Our dissection protocol for both crab species was based on protocols by Torchin et al. (2001) and J.E.B. (unpubl.), which consisted of removing the crab's carapace and first visually inspecting all tissues under a dissecting microscope. We then systematically examined tissues from the crab's digestive cecum, body cavity, reproductive tissues, and thoracic ganglia under a compound microscope for the presence of metazoan parasites (e.g. acanthocephalans, cestodes, nematodes, trematodes). All crabs examined were fresh (not preserved) when dissected.

To quantify a host's escape from parasites, we calculated the proportional parasite escape for each crab species, which is: $(N-I) / N$, where $N=$ the total parasite species richness of the native region and $I=$ total para- site species richness of the introduced region (Torchin et al. 2003). For both Carcinus maenas and Hemigrapsus sanguineus, our total species richness and parasite escape calculations included a combination of field and literature data. For all other richness and prevalence analyses, we used our field data only (i.e. we did not include literature records) to be consistent with the Torchin et al. (2001) and previously unpublished field data (M.E.T., A.M.K., K.D.L.), which explored particular parasite taxa (acanthocephalans, cestodes, epicaridean isopods, microsporans, nematodes, nemerteans, rhizocephalans, and trematodes) rather than species-level richness. We calculated proportional parasite prevalence as: $n_{i} / n$, where $n_{i}=$ number of infected individuals and $n=$ number of total individuals, con- 


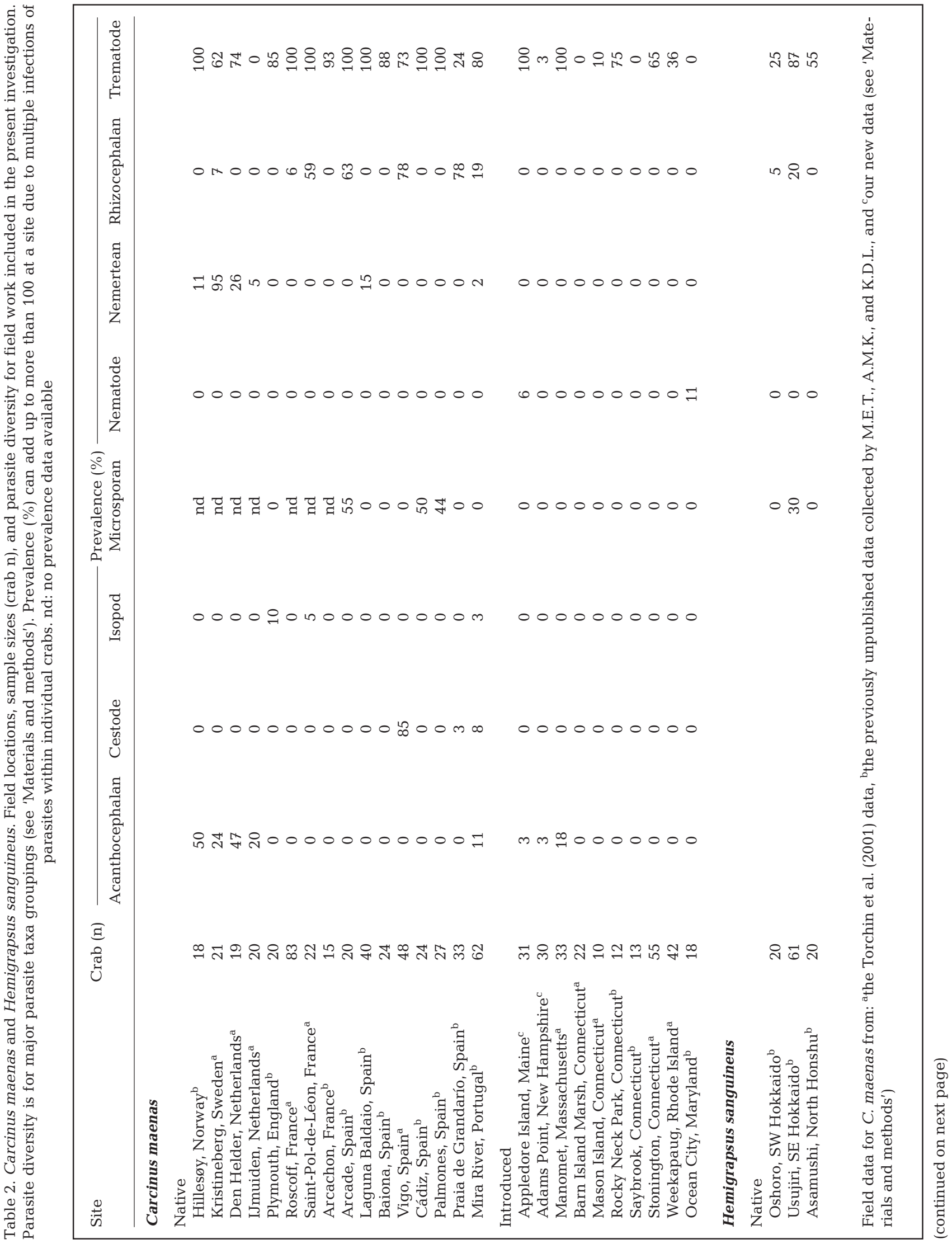




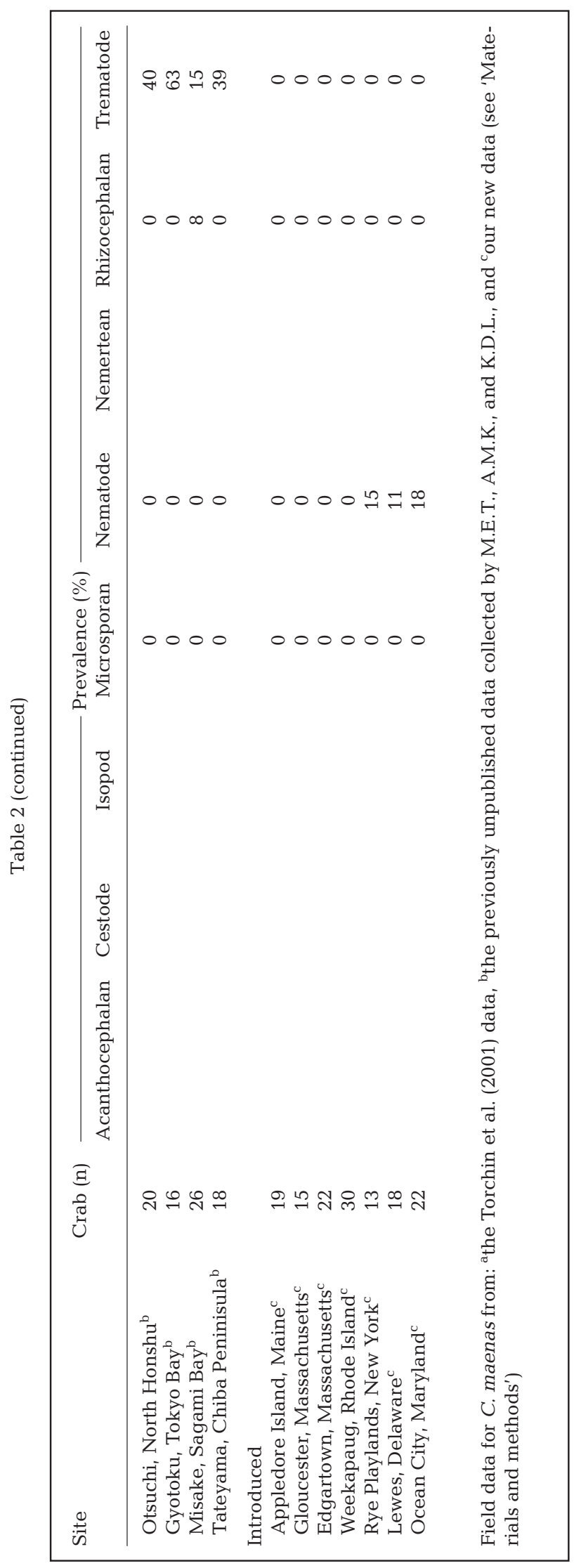

verting prevalence values to percentages. Because castrating and trophically transmitted parasites (which include trematodes) have different effects on host fitness, we further divided our parasite prevalence data into these 2 major parasite groupings, following the approach of Torchin et al. (2001).

Because sampling effort for each crab species and region were not equal in our study, we performed 2 standardization techniques to account for the differences in sampling effort. These standardization analyses included published (Torchin et al. 2001), previously unpublished (M.E.T., A.M.K., K.D.L.), and new field data (all presented in Table 2). Firstly, we constructed species rarefaction curves that depict species accumulation and species estimation (i.e. Chao2 estimator) with sampling effort (in EstimateS 8.0; Colwell 2006). Because clearly asymptoting accumulation curves suggest complete capture of the total species richness in a population (Gotelli \& Colwell 2001), estimator curves and species accumulation curves converging on the same asymptote reflect adequate sampling (Walther \& Morand 1998, Blakeslee \& Byers 2008). We therefore used this technique to determine whether our sampling had been adequate across crab species and populations, or whether differences in sampling effort and area would impact our observed species richness comparisons. Specifically, we used the Chao2 estimator because it has been shown to be robust in many systems and advocated for parasite studies (Walther \& Morand 1998); the Chao2 bias-corrected equation (see Colwell 2006) is:

$$
\hat{S}_{\text {Chao } 2}=S_{\text {obs }}+\frac{m-1}{m} \times \frac{Q_{1}\left(Q_{1}-1\right)}{2\left(Q_{2}+1\right)}
$$

where $\hat{S}_{\text {Chao2 }}$ is the species richness estimate; $S_{\text {obs }}$ is the total number of species observed in all samples pooled; $m$ is the total number of samples; $Q_{1}$ is the frequency of uniques (species that occur in only 1 sample); and $Q_{2}$ is the frequency of duplicates (species that occur in only 2 samples). For our investigation, 'samples' were sample sites. Although our data were sample-based, we rescaled our species accumulation curves to accumulated individuals (see Fig. 3) in order to compare species richness across our data sets in a standardized manner (Gotelli \& Colwell 2001). Secondly, we used Monte Carlo resampling (in EstimateS 8.0; Colwell 2006) to standardize sample sizes across populations and crab species at the lowest common sample size $(\mathrm{n}=15$ crabs) for a site and adjusted our richness values for each site based on the results of the analysis. We then used these site-level parasite richness values to compare crab species across populations using Student's pairwise $t$-tests (significance was determined at $\alpha=0.05$ ). 
Although our comparisons of site-level parasite richness standardize for sampling effort and overall regional sample size when comparing native and non-native crab populations, we performed an additional conservative analysis for Carcinus maenas. This was because we sampled a much larger geographic range of $C$. maenas on the European coast compared to the US East Coast (in contrast, the sampled native and non-native regions for Hemigrapsus sanguineus were of similar geographic sizes). We therefore examined a subset of our C. maenas data from a central/western sampling region (6 sites: Arcachon, France; Saint-Pol-de-Léon, France; Roscoff, France; Plymouth, England; IJmuiden, Netherlands; and Den Helder, Netherlands) over a geographic size $(\sim 1000 \mathrm{~km})$ that was more similar (using a rough, linear distance) to the US East Coast range $(\sim 700 \mathrm{~km})$ we investigated. We focused on this central region of the European range for 2 reasons: (1) our sample sites on the US East Coast were also primarily from the central region of the crab's range (which extends from Virginia, USA, to Newfoundland, Canada) and overlap the region where the crab was initially introduced and rapidly spread in the 19th century (Carlton \& Cohen 2003); (2) the European source region for $C$. maenas' introduction overlaps much of the western European area we included in our subset (i.e. sites southwest of Bremerhaven, Germany; Roman 2006). Of note, however, is that these comparative ranges (the native subset region and the introduced region) are latitudinally different; exploring similar latitudes would have represented only the southern portion of the crab's European range.

\section{RESULTS}

\section{Carcinus maenas}

In its native European range, Carcinus maenas is infected by 10 parasite species compared to 3 in its introduced US East Coast range (Table 1), and the crab's proportional parasite escape is 0.70. All parasites found on the East Coast were a subset of the European parasite fauna, except for an (as yet) unidentified larval nematode on the East Coast. This may be the same nematode reported in Torchin et al. (2001) for both C. maenas and Hemigrapsus sanguineus. Overall prevalence of infection in native European populations was $24 \%$ for castrating parasites and $89 \%$ for trophically transmitted parasites (summed parasite prevalence can be greater than $100 \%$ due to dual infections in both categories), while for introduced East Coast populations, castrating parasite prevalence was $0 \%$ and trophically transmitted parasite prevalence was $49 \%$ (Fig. 2a). At the site level, average prevalences were similar to the overall prevalences for both native and introduced populations (Fig. 2b). Altogether, parasite prevalence (primarily dominated by trematode infections) in the introduced range was approximately half that of the native European range (Fig. 2). While sampling effort was not equal across populations, our rarefaction analyses found the total expected parasite richness to be equivalent to the observed richness values for both native and introduced regions (Fig. 3a,b), suggesting that sampling was adequate to capture the
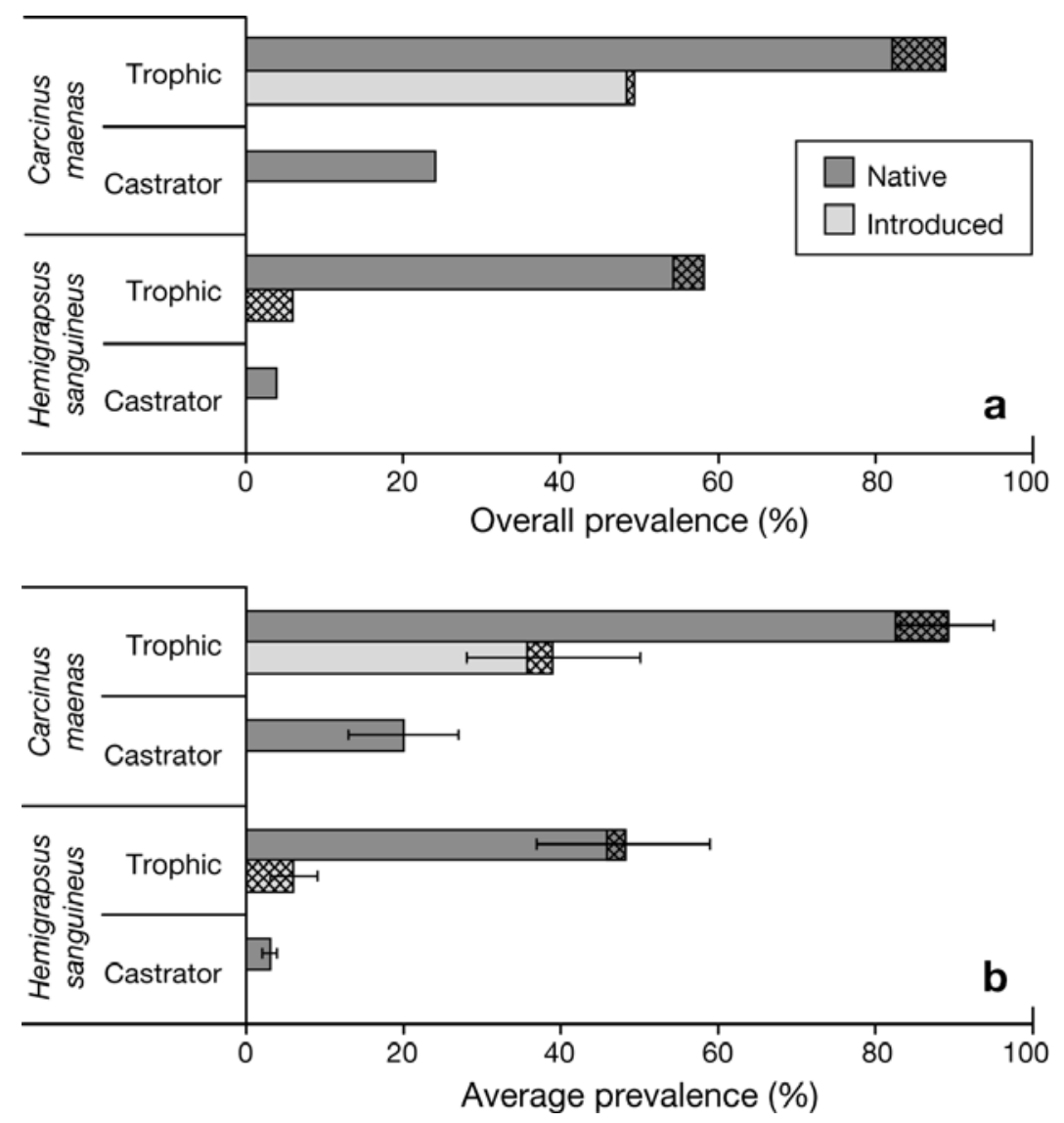

Fig. 2. Prevalence in Carcinus maenas and Hemigrapsus sanguineus for native and introduced regions of the 2 parasite groupings (castrator and trophic): (a) overall prevalence; (b) average site-level prevalence. Stacked bars represent proportion of metacercaria (trematode) and non-metacercaria infections within trophically transmitted prevalence (cross hatching $=$ non-metacercaria prevalence). Data included in prevalence analyses are from field records (see 'Materials and methods') 

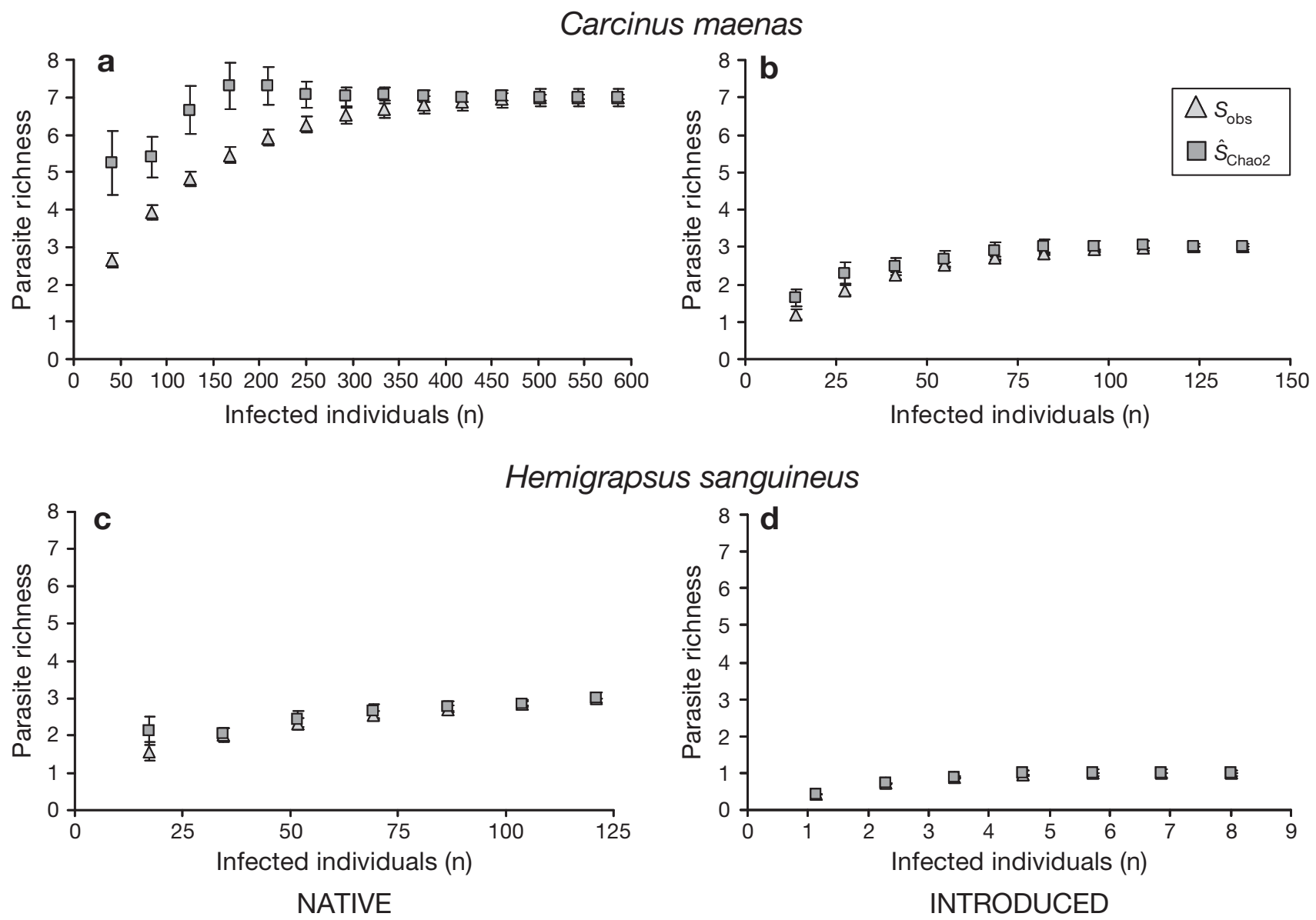

Fig. 3. Parasite rarefaction curves for $(\mathrm{a}, \mathrm{b})$ Carcinus maenas and $(\mathrm{c}, \mathrm{d})$ Hemigrapsus sanguineus in native and introduced regions. Curves portray the accumulation of parasites (number of species observed, $S_{\text {obs }}$ ) and the expected parasite richness $\left(\hat{S}_{\text {Chao2 }}\right)$ as a function of the number of infected individuals in each population and for each crab species. Error bars (some error bars are small and difficult to discern) are SE for 500 runs in EstimateS (Colwell 2006), and data were from field records only (see 'Materials and methods'). These analyses not only demonstrate each crab's parasite escape but also that sampling effort (though not equal) adequately reflected underlying richness in each population

underlying parasite richness in native and introduced populations. Our second standardization method used a Monte Carlo resampling analysis to explore average $( \pm \mathrm{SE})$ parasite richness across sites and resulted in a site-level richness of $2.31 \pm 0.22$ in Europe compared to $1.38 \pm 0.15$ on the US East Coast, which was a significant reduction $(p=0.013)$ (Fig. 4, Appendix 1). In the analysis where we explored a subset of our European field data, we found total species richness to be 6 taxa in Europe as opposed to 3 on the US East Coast, representing a parasite escape of 0.50. Parasite prevalence averaged ( $\pm \mathrm{SE}$ ) across the 6 sites was $10.8 \pm 9.7 \%$ for castrating parasites and $78.8 \pm 12.4 \%$ for trophically transmitted parasites. When these results were compared to those from the US East Coast, C. maenas continued to show a large reduction (close to half that of Europe) in prevalence in its introduced range compared to the subset we explored in its native range.

\section{Hemigrapsus sanguineus}

Hemigrapsus sanguineus is infected by 6 parasite species in its native Asian range compared to 1 in its introduced US East Coast range (Table 1), and the crab's escape from parasites is 0.83. In Asia, overall parasite prevalence was $4 \%$ for castrating parasites and $58 \%$ for trophically transmitted parasites, and on the US East Coast, prevalence was $0 \%$ for castrating parasites and $6 \%$ for trophically transmitted parasites (Fig. 2a); site-level average prevalence in both regions was again similar to the crab's overall prevalence (Fig. $2 \mathrm{~b})$. On the whole, parasite prevalence in the introduced US range was about $90 \%$ lower than native Asia (Fig. 2) and was represented by only 1 parasite taxon (larval nematode). Interestingly, we found this nematode to be limited to the southern areas of its sampled range (Rye, NY, and southwards; see Fig. 1), which is within the general area of its initial founding region. 


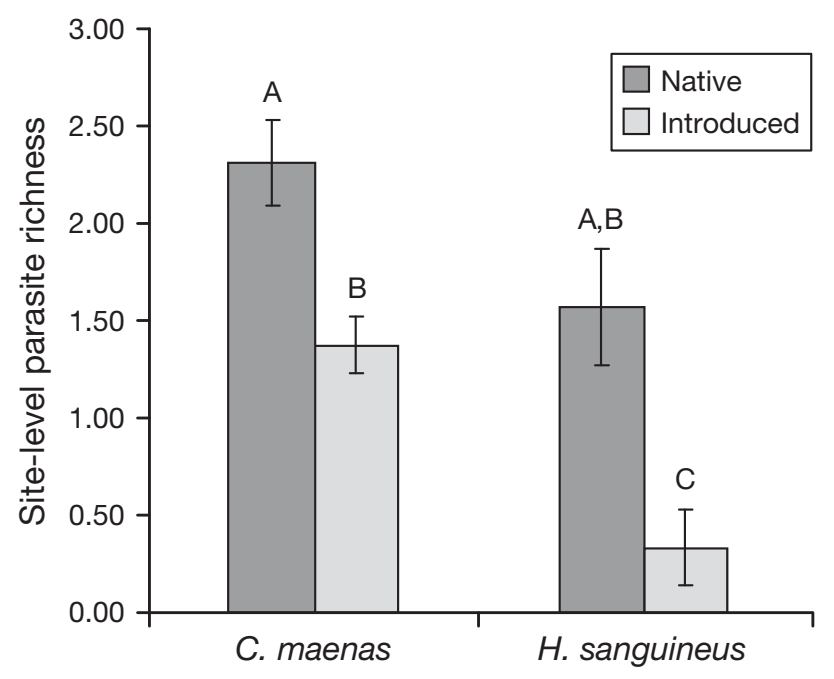

Fig. 4. Carcinus maenas and Hemigrapsus sanguineus. Standardized site-level parasite richness for taxa in native and introduced populations across sites. Data included in these analyses are from field records only and richness was standardized (Appendix 1) using a Monte Carlo resampling analysis (see 'Materials and methods'). Significance values (A, B, C) are based on pairwise comparisons from Student's $t$-tests

Sample size was again unbalanced between the regions; yet our species rarefaction curves found that the total expected parasite richness was equivalent to the observed richness values in both regions (Fig. $3 \mathrm{c}, \mathrm{d})$. Finally, standardization of our Asian and East Coast field data resulted in the average $( \pm \mathrm{SE})$ sitelevel parasite richness for Asian sites to be $1.57 \pm 0.30$ and for US East Coast sites to be $0.33 \pm 0.20$, a significant reduction ( $\mathrm{p}=0.011$ ) (Fig. 4, Appendix 1).

\section{Comparison of crab species}

The magnitude of escape from parasites differed between the 2 crab species. Altogether, Hemigrapsus sanguineus' escape from parasites (0.83) was 1.2 times greater than that of Carcinus maenas (0.70) when including field and literature data. Furthermore, the reduction in parasite prevalence in introduced versus native populations was about twice as great for $H$. sanguineus as for C. maenas, e.g. Fig. 1 visually displays this overall reduction in parasite prevalence in the introduced range compared to both crabs' native ranges, especially for $H$. sanguineus, where the majority of sites had zero prevalence. Comparing just within the introduced East Coast range, parasite prevalence in $H$. sanguineus was more than an order of magnitude lower than prevalence in C. maenas (Fig. 2) and $H$. sanguineus had a significantly $(\mathrm{p}=0.025)$ lower parasite richness than did C. maenas in their overlapping introduced range (Fig. 4). Overall, our standardization techniques imply that we approached complete capture of parasite richness in all populations and for both crab species (Figs. 3 \& 4), suggesting sampling bias was unlikely to contribute to the differences we observed between the 2 crab species. When we compared our $H$. sanguineus data set to the C. maenas subset data set (i.e. the subset of the European population from which $C$. maenas was most likely introduced), $H$. sanguineus' escape from parasites (0.83) was about 1.7 times greater than that of C. maenas (0.50), and average parasite prevalence was again about twice as reduced for $H$. sanguineus as for C. maenas in introduced versus native ranges.

\section{DISCUSSION}

Carcinus maenas and Hemigrapsus sanguineus populations showed a significant decline in both parasite species richness and prevalence in their introduced range (the US East Coast) compared to their native ranges (Europe and Pacific Asia, respectively). However, $H$. sanguineus' escape from parasites was 1.2 times greater than that of $C$. maenas (1.7 times greater when the $H$. sanguineus data was compared to the $C$. maenas subset data), and site-level parasite richness was significantly lower for $H$. sanguineus than $C$. maenas in their overlapping introduced range along the US East Coast. Also, H. sanguineus' reduction in parasite prevalence was about twice that experienced by $C$. maenas in the crabs' overlapping introduced range for the whole data set as well as the European subset data. Altogether, we found $H$. sanguineus to be infected (both absolutely and proportionally) by fewer parasites on the US East Coast than C. maenas, which we have shown is unlikely affected by sampling bias. Moreover, it is not the case that $H$. sanguineus is restricted to areas where the parasites infecting $C$. maenas do not exist, since $H$. sanguineus overlaps with $C$. maenas in the primarily rocky intertidal habitat where these parasites were found infecting the green crab. Even when we restricted our comparison of $H$. sanguineus and $C$. maenas to sites where both species co-occurred, $C$. maenas continued to show a greater species richness and prevalence of infection than $H$. sanguineus, consistent with patterns we observed at the overall population level.

Escape of introduced populations from parasites (both richness and prevalence) is common across taxa (Torchin et al. 2002, 2003) and has been suggested as a potential advantage for introduced host species that are released from detrimental fitness effects induced by parasitic infections (e.g. Elton 1958, Dobson 1988, Byers 2000, Torchin et al. 2001). For Carcinus maenas, 
evidence has been found demonstrating physiological and likely ecological benefits due to the crab's release from parasites in its introduced populations (Torchin et al. 2001). In particular, demographic performance (individual size and biomass) of European C. maenas crabs declines with increasing prevalence of parasitic castrators (which block reproduction and retard growth), and these parasitic castrators are absent in the crab's introduced East Coast population (Torchin et al. 2001). For H. sanguineus, it is not yet known whether the crab's escape from parasites will result in similar advantages in its introduced range. However, like $C$. maenas, $H$. sanguineus may benefit from its substantial decline in parasite infection on the US East Coast, particularly the absence of parasitic castrators, which, though relatively rare across its native range, have been found at some sites to infect the crab at high prevalences (e.g. Korn et al. 2004) and can greatly reduce its fitness (Yamaguchi et al. 1984, Takahashi \& Matsuura 1994, Isaeva et al. 2001, 2005, Korn et al. 2004).

While both crabs experience a reprieve from parasitic castrators on the East Coast, Carcinus maenas is infected by a significantly greater prevalence and richness of trophically transmitted parasites than is Hemigrapsus sanguineus in this same region. In particular, C. maenas' most common East Coast parasite (overall prevalence of $\sim 40 \%$ ) is a trophically transmitted trematode, Microphallus similis, which encysts as metacercariae (often with hundreds of cysts) within the crab's tissues. Metacercarial infections (and microphallid infections in particular) have been found to damage internal tissues (Martorelli \& Schuldt 1990, Robaldo et al. 1999) and impact host growth (Thieltges 2006), and can induce mortality (Meissner \& Bick 1999, Fredensborg et al. 2005). While M. similis often occurs at high prevalence and intensity in East Coast C. maenas populations, our survey of the US East Coast found no natural infections of $M$. similis in $H$. sanguineus, nor could infection be induced experimentally (C.L.K. unpubl.), even though $H$. sanguineus is infected by 3 trematode species, including a microphallid, in its native range (Table 1). Although fitness effects of $M$. similis infection on crab hosts have not yet been investigated, $M$. similis may confer similar fitness disadvantages as those induced by other microphallids infecting other crustacean hosts (e.g. Martorelli \& Schuldt 1990, Robaldo et al. 1999). Such a scenario could play a role in the green crab's displacement by its healthier competitor, $H$. sanguineus. In particular, $H$. sanguineus can be more aggressive than $C$. maenas and often wins competitive interactions between the species (e.g. Jensen et al. 2002, Griffen \& Williamson 2008). Parasitism could directly alter the behavior of heavily infected crabs (i.e. unhealthy crabs may not be as aggressive), potentially influencing these interactions. On the other hand, infection status may not directly influence the competitive abilities of the crabs per se, but rather, operating indirectly, i.e. by differentially reducing fecundity or increasing mortality of one competitor species, they may free up more resources for the other species (Byers \& Goldwasser 2001).

As we have described, Carcinus maenas is infected by a greater richness and prevalence of parasites on the US East Coast than Hemigrapsus sanguineus, and there are several potential non-mutually exclusive explanations for this observation. (1) Susceptibility: $C$. maenas may be more susceptible to parasitism than $H$. sanguineus, either because its biology and/or ecology put it in greater contact with parasites, or because it is physiologically more susceptible. (2) Time since introduction: C. maenas has been present on the US East Coast for almost 2 centuries while $H$. sanguineus only invaded within the last 2 decades. This increases opportunities for both the invasion of other parasites from C. maenas' native range and the potential to become infected by native East Coast parasites. Torchin \& Lafferty (2008) found a significant linear relationship (explaining $83 \%$ of the variability in the number of parasite species in introduced populations) between age of introduced populations and parasite species richness, specifically for C. maenas in its various introduced populations around the world. (3) Introduction vector: C. maenas is believed to have been introduced with rock ballast (Roman \& Darling 2007), such that infected adult crabs could have been present among the crab's initial introduced population(s), while $H$. sanguineus was likely introduced as larvae in ballast water (McDermott 1998), making introduction of infected individuals very unlikely. (4) Distance from native range: C. maenas is a North Atlantic species, and the distance from its native range to the US East Coast is considerably closer than that of $H$. sanguineus, which is an Asian Pacific species. Thus, the relatively close proximity of the US East Coast to the European shoreline (compared to Asia) would allow for greater ease of parasite transport from the native range. Consistent with this hypothesis (and Hypothesis 2 above), C. maenas is only infected by one parasite in its recent introduced population on the US West Coast, where it invaded just within the last couple of decades (Torchin et al. 2001). (5) Taxonomic isolation: There are native portunid crabs that may serve as sources of parasites for $C$. maenas on the US East Coast, but there are no native grapsids in the same region as sources for parasite transfer to $H$. sanguineus. (6) Parasite identification bias: C. maenas parasitism has been studied to a greater degree than $H$. sanguineus over the years; however, because our rarefaction curves (Fig. 3) suggest complete capture of parasites across regions and 
crab species, this scenario may not be as likely as the others. On the whole, H. sanguineus could remain relatively parasite-free for a long period of time because of these various factors.

Overall, our results show a significant decline in parasite richness and prevalence of infection for both crab species in their introduced range, likely providing substantial advantages for each species. However, Hemigrapsus sanguineus has clearly experienced a greater reprieve from parasitism on the US East Coast, which may have aided the crab in competitively displacing Carcinus maenas in many East Coast populations. The reduction in C. maenas abundance has likely had (and is currently having) considerable community-wide impacts, including predatory influences (DeGraaf \& Tyrrell 2004, Griffen et al. 2008, Griffen \& Byers 2009), competitive impacts with native crab species (Lohrer \& Whitlatch 2002), and it may also influence cascading effects in areas where $H$. sanguineus has become the dominant shorecrab. For example, displacement of $C$. maenas will likely impact parasite communities, especially trophically transmitted parasites using the green crab as a host for larval stages. The possible extirpation or drastic reduction of these relatively host-specific parasites could actually benefit native hosts to the extent that these hosts are involved in parasite life cycles involving C. maenas. For example, the trematode Microphallus similis uses native littorine snails, Littorina saxatilis and L. obtusata, as first-intermediate hosts on the US East Coast (Blakeslee \& Byers 2008). The competitive exclusion of $C$. maenas by $H$. sanguineus could result in lower $M$. similis infection prevalences in these snails (potentially advantageous since $M$. similis castrates snail hosts). Such a scenario has been shown on the US West Coast, where an introduced snail, Batillaria attramentaria (Asian mudsnail), is competitively displacing the native California horn snail Cerithidea californica in several west coast populations. The native snail is infected by 10 trematode parasites, while in this same region, the non-native snail, B. attramentaria, is infected by just one morphologically distinct trematode species (also a non-native). (Of note, however, is that this trematode species has recently been found to be a complex of multiple genetically distinct cryptic species, 3 of which invaded the west coast with B. attramentaria; Miura et al. 2006). With the exclusion of $C$. californica by $B$. attramentaria, it is believed the 10 native parasites will go locally extinct, likely impacting other hosts (including crustaceans, mollusks, fish, and mammals) involved in the trematode life cycles (Torchin et al. 2005). Similar community-wide effects might also occur on the US East Coast where $H$. sanguineus is presently displacing C. maenas (although dissimilar from the example above, this system involves a non-native replacing another non-native species). On the whole, our investigation underscores not just that non-native species lose parasites upon introduction, but that they may do so differentially, with ramifications for their direct interactions and with potential community-level influences.

Acknowledgements. We thank I. Altman, M. Blakeslee, J. Carlton, J. Dijkstra, C. Hamer, R. Hechinger, R. Houghton, R. Seeley, G. Vazquez-Prokopec, the Shoals Marine Lab, the 2007 SML REU students, and the SERC Marine Invasions lab. A.M.H.B. and C.L.K. were funded by the Isles of Shoals NSF REU program. A.M.K. and K.D.L. were funded by the following sources: CSIRO Australia Marine Division, the National Sea Grant College Program, National Oceanic and Atmospheric Administration (NOAA), US Department of Commerce under grant number NA06RG0142, project number R/CZ162, through the California Sea Grant College System, and in part by the California State Resources Agency, and by the NSF/NIH Ecology of Infectious Diseases Program (NSF DEB0224565). Collaboration on this work was also facilitated by the Global Invasions Network NSF RCN DEB-0541673.

\section{LITERATURE CITED}

Ahl RS, Moss SP (1999) Status of the nonindigenous crab, Hemigrapsus sanguineus, at Greenwich Point, Connecticut. Northeast Nat 6:221-224

Blakeslee AMH, Byers JE (2008) Using parasites to inform ecological history: comparisons among three congeneric marine snails. Ecology 89:1068-1078

Bourdon R (1960) Rhizocephales et isopodes parasites des décapodes marcheurs de la Baie de Quiberon. Bull Soc Sci Nancy 19:134-153

Bourdon R (1963) Epicarides et rhizocephales de Roscoff. Cah Biol Mar 4:415-434

Bourdon R (1964) Epicarides et rhizocephales du Bassin d'Arcachon. Proc-Verb Soc Linn Bordeaux 101:1-7

Brattey J, Elner RW, Uhazy LS, Bagnall AE (1985) Metazoan parasites and commensals of five crab (Brachyura) species from eastern Canada. Can J Zool 63:2224-2229

Bridgman JF (1971) The life cycle of Maritrema setoensis n. sp. (Trematoda: Microphallidae). Jpn J Parasitol 20:13-23

Byers JE (2000) Competition between two estuarine snails: implications for invasions of exotic species. Ecology 81: 1225-1239

Byers JE, Goldwasser L (2001) Exposing the mechanism and timing of impact of nonindigenous species on native species. Ecology 82:1330-1343

Carlton JT, Cohen AN (2003) Episodic global dispersal in shallow water marine organisms: the case history of the European shore crabs Carcinus maenas and C. aestuarii. J Biogeogr 30:1809-1820

Carlton JT, Geller JB (1993) Ecological roulette: the global transport of nonindigenous marine organisms. Science 261:78-82

Castilho F, Barandela T (1990) Ultrastructural study on the spermatogenesis and spermatozoon of the metacercariae of Microphallus primas (Digenea), a parasite of Carcinus maenas. Mol Reprod Dev 25:140-146

Cohen AN, Carlton JT (1998) Accelerating invasion rate in a highly invaded estuary. Science 279:555-558

Colwell RK (2006) EstimateS: statistical estimation of species richness and shared species from samples. Version 8.0. User's guide: http://viceroy.eeb.uconn.edu/estimates 
Comely CA, Ansell AD (1989) The incidence of Carcinonemertes carcinophila (Kolliker) on some decapod crustaceans from the Scottish West Coast. Ophelia 30: 225-233

Crothers JH (1968) The biology of the shore crab Carcinus maenas (L.) 2. The life of the adult crab. Field Stud 2: 579-614

DeGraaf JD, Tyrrell MC (2004) Comparison of the feeding rates of two introduced crab species, Carcinus maenas and Hemigrapsus sanguineus, on the blue mussel, Mytilus edulis. Northeast Nat 11:163-166

> Delaney DG, Sperling CD, Adams C, Leung B (2008) Marine invasive species: validation of citizen science and implications for national monitoring networks. Biol Invasions 10: $117-128$

> Dobson AP (1988) Restoring island ecosystems: the potential of parasites to control introduced mammals. Conserv Biol 2:31-39

Elton CS (1958) The ecology of invasions by animals and plants. Methuen, London

Fredensborg BL, Mouritsen KN, Poulin R (2005) Impact of trematodes on host survival and population density of the intertidal gastropod Zeacumantus subcarinatus. Mar Ecol Prog Ser 290:109-117

Freeman AS, Byers JE (2006) Divergent induced responses to an invasive predator in marine mussel populations. Science 313:831-833

Glude JB (1955) The effects of temperature and predators on the abundance of the soft-shell clam Mya arenaria in New England. Trans Am Fish Soc 84:13-26

Gotelli NJ, Colwell RK (2001) Quantifying biodiversity: procedures and pitfalls in the measurement and comparison of species richness. Ecol Lett 4:379-391

Griffen BD, Byers JE (2009) Community impacts of two invasive crabs: the interactive roles of density, prey recruitment, and indirect effects. Biol Invasions 11:927-940

Griffen BD, Williamson T (2008) Influence of predator density on nonindependent effects of multiple predator species. Oecologia 155:151-159

Griffen BD, Guy T, Buck JC (2008) Inhibition between invasives: a newly introduced predator moderates the impacts of a previously established invasive predator. J Anim Behav 77:32-40

Humes AG (1942) The morphology, taxonomy, and bionomics of the nemertean genus Carcinonemertes. III. Biol Monogr 18:1-105

Isaeva V, Kulikova V, Kasyanov V (2001) Bivalve molluscs, Mytilus trossulus and Hiatella arctica, as facultative epibionts of the crab, Hemigrapsus sanguineus, infested by the rhizocephalan, Sacculina polygenea. J Mar Biol Assoc UK 81:891-892

Isaeva V, Dolganov S, Shukalyuk A (2005) Rhizocephalan barnacles-parasites of commercially important crabs and other decapods. Russ J Mar Biol 31:215-220

> Jensen GC, McDonald PS, Armstrong DA (2002) East meets west: competitive interactions between green crab Carcinus maenas, and native and introduced shore crab Hemigrapsus spp. Mar Ecol Prog Ser 225:251-262

Kifune T, Koga T (1999) Metacercaria of Microphalloides japonicus (Digenea: Microphallidae) found in Ilyoplax pusilla (Decapoda: Ocypodidae) on the seashore of the eastern part of Fukuoka City, Kyushu, Japan. Trans Nagasaki Biol Soc 50:5-8

Korn OM, Rybakov AV, Kashenko SD (2000) Larval development of the rhizocephalan Sacculina polvaenea (Crustacea: Cirripedia). Russ J Mar Biol 26:373-377

Korn OM, Shukalyuk AI, Trofimova AV, Isaeva VV (2004)
Reproductive stage of the life cycle in the rhizocephalan barnacle Polyascus polygenea (Crustacea: Cirripedia). Russ J Mar Biol 30:328-340

> Kraemer GP, Sellberg M, Gordon A, Main J (2007) Eight-year record of Hemigrapsus sanguineus (Asian shore crab) invasion in western Long Island sound estuary. Northeast Nat 14:207-224

Kuris AM, Lafferty KD, Torchin ME (2005) Biological control of the European green crab, Carcinus maenas: natural enemy evaluation and analysis of host specificity. In: Hoddle MS (ed) 2nd Int Symp Biological Control of Arthropods, Sept 12-16, 2005, Davos. USDA Forest Service, Washington, DC, p 102-115

Lohrer AM, Whitlatch RB (2002) Interactions among aliens: apparent replacement of one exotic species by another. Ecology 83:719-732

Lützen J, Takahashi T (1997) Sacculina polygenea, a new species of rhizocephalan (Cirripedia: Rhizocephala) from Japan, parasitic on the intertidal crab Hemigrapsus sanguineus (De Haan, 1835) (Decapoda: Brachyura: Grapsidae). Crustac Res 26:103-108

Martorelli SR, Schuldt M (1990) Encapsulation of two metacercariae (Digenea, Microphallidae) in Cyrtograpsus angulatus and Palaemonetes argentinus (Crustacea, Decapoda). Rev Biol Trop 38:295-304

Mathieson S, Berry AJ, Kennedy S (1998) The parasitic rhizocephalan barnacle Sacculina carcini in crabs of the Forth Estuary, Scotland. J Mar Biol Assoc UK 78:665-667

McDermott JJ (1998) The western Pacific brachyuran (Hemigrapsus sanguineus: Grapsidae) in its new habitat along the Atlantic coast of the United States: geographic distribution and ecology. ICES J Mar Sci 55:289-298

McDermott JJ (2007) Ectosymbionts of the non-indigenous Asian shore crab, Hemigrapsus sanguineus (Decapoda: Varunidae), in the western north Atlantic, and a search for its parasites. J Nat Hist 41:2379-2396

- Meissner K, Bick A (1999) Mortality of Corophium volutator (Amphipoda) caused by infestation with Maritrema subdolum (Digenea, Microphallidae) - laboratory studies. Dis Aquat Org 35:47-52

> Minchella DJ, Scott ME (1991) Parasitism: a cryptic determinant of animal community structure. Trends Ecol Evol 6: $250-254$

Minchin D (1997) The influence of the parasitic cirripede Sacculina carcini on its brachyuran host Carcinus maenas within its home range. In: Thresher R (ed) Proc 1st Int Workshop on the Demography, Impacts and Management of the Introduced Populations of the European Crab, Carcinus maenas, Mar 20-21, 1997, Hobart. Centre for Research on Introduced Marine Pests. Technical Report Number 11. CSIRO Marine Laboratories, Hobart, p 76-79

Miura O, Torchin ME, Kuris AM, Hechinger RF, Chiba S (2006) Introduced cryptic species of parasites exhibit different invasion pathways. Proc Natl Acad Sci USA 103: 19818-19823

Otagaki H (1958) A study on some trematodes whose intermediate hosts are crabs inhabiting mouth of rivers flowing into Inland Sea of Japan. Jpn J Parasitol 7:167-182

Rasmussen E (1973) Systematics and the ecology of the Isefjord marine fauna (Denmark). Ophelia 11:142-165

> Robaldo RB, Monserrat J, Cousin JCB, Bianchini A (1999) Effects of metacercariae (Digenea: Microphallidae) on the hepatopancreas of Chasmagnathus granulata (Decapoda: Grapsidae). Dis Aquat Org 37:153-157

Roman J (2006) Diluting the founder effect: cryptic invasions expand a marine invader's range. Proc R Soc Lond B Biol Sci 273:2453-2459 
Roman J, Darling JA (2007) Paradox lost: genetic diversity and the success of aquatic invasions. Trends Ecol Evol 22: $454-464$

Ropes JW (1968) The feeding habits of the green crab, Carcinus maenas (L.). US Fish Wildl Serv Fish Bull 67:183-203

Ruiz GM, Fofonoff PW, Carlton JT, Wonham MJ, Hines AH (2000) Invasion of coastal marine communities in North America: apparent patterns, process, and biases. Annu Rev Ecol Syst 31:481-531

Sax DF, Stachowicz JJ, Brown JH, Bruno JF and others (2007) Ecological and evolutionary insights from species invasions. Trends Ecol Evol 22:465-471

Settle WH, Wilson LT (1990) Invasion by the variegated leafhopper and biotic interactions: parasitism, competition, and apparent competition. Ecology 71:1461-1470

Stunkard HW (1956) Studies on the parasites of the green crab, Carcinides maenas. Biol Bull 111:295

Takahashi T, Matsuura S (1994) Laboratory studies on molting and growth of the shore crab, Hemigrapsus sanguineus de Haan, parasitized by a rhizocephalan barnacle. Biol Bull 186:300-308

Thieltges DW (2006) Effect of infection by the metacercarial trematode Renicola roscovita on growth in intertidal blue mussel Mytilus edulis. Mar Ecol Prog Ser 319: 129-134

Thompson AB (1985) Analysis of Profilicollis botulus (Acanthocephala: Echinorhynchidae) burdens in the shore crab, Carcinus maenas. J Anim Ecol 54:595-604

Torchin ME, Lafferty KD (2008) Escape from parasites. In: Rilov G, Crooks J (eds) Marine bioinvasions: ecology, conservation and management perspectives. Springer-Ver- lag, Berlin, p 203-214

Torchin ME, Mitchell CE (2004) Parasites, pathogens, and invasions by plants and animals. Front Ecol Environ 2: 183-190

Torchin ME, Lafferty KD, Kuris AM (2001) Release from parasites as natural enemies: increased performance of a globally introduced marine crab. Biol Invasions 3:333-345

- Torchin ME, Lafferty KD, Kuris AM (2002) Parasites and marine invasions. Parasitology 124:S137-S151

> Torchin ME, Lafferty KD, Dobson AP, McKenzie VJ, Kuris AM (2003) Introduced species and their missing parasites. Nature 421:628-630

Torchin ME, Byers JE, Huspeni TC (2005) Differential parasitism of native and introduced snails: replacement of a parasite fauna. Biol Invasions 7:885-894

Tyrrell MC, Harris LG (1999) Potential impact of the introduced shore crab Hemigrapsus sanguineus in northern New England: diet, feeding preferences, and overlap with the green crab, Carcinus maenas. In: Pedersen J (ed) Marine bioinvasions. Proc 1st Natl Conf, Jan 24-27, 1999, Cambridge, MA. MIT Sea Grant College Program, Cambridge, MA, p 208-220

Tyrrell MC, Guarino PA, Harris LG (2006) Predatory impacts of two introduced crab species: inferences from microcosms. Northeast Nat 13:375-390

- Walther BA, Morand S (1998) Comparative performance of species richness estimation methods. Parasitology 116: 395-405

Yamaguchi T, Tokunaga S, Aratake H (1984) Contagious infections by the rhizocephalan parasite Sacculina sp. in the grapsid crab Hemigrapsus sanguineus (De Haan). Crustac Res 23:89-101

Appendix 1. Site locations, sample sizes, parasite richness, and standardized site-level species richness (adjusted richness) for parasite taxa in native (Carcinus maenas: Europe; Hemigrapsus sanguineus: Asia) and introduced (both crabs: US East Coast) populations. Adjusted richness values were based on a Monte Carlo sampling technique at the lowest common number of crabs $(\mathrm{n}=15)$ (see 'Materials and methods'). In one case, sites were lumped together due to their close proximity (Rocky Neck and Saybrook, CT). Only sites with 15 crabs or more are included in adjusted richness analyses (thus these analyses excluded one site: Rye Playlands, NY, for $H$. sanguineus). Data included in these analyses were from field records (see 'Materials and methods')

\begin{tabular}{llll}
\hline Sites & Sample size & Richness & Adjusted richness \\
\hline Carcinus maenas & & & \\
Europe & & 3 & 3 \\
Hillesøy, Norway & 18 & 4 & 3 \\
Kristineberg, Sweden & 21 & 3 & 3 \\
Den Helder, Netherlands & 19 & 2 & 1 \\
IJmuiden, Netherlands & 20 & 2 & 2 \\
Plymouth, England & 20 & 2 & 2 \\
Roscoff, France & 83 & 3 & 3 \\
Saint-Pol-de-Léon, France & 22 & 1 & 1 \\
Arcachon, France & 15 & 3 & 3 \\
Arcade, Spain & 20 & 2 & 2 \\
Laguna Baldaio, Spain & 40 & 1 & \\
Baiona, Spain & 24 & 3 & 3 \\
Vigo, Spain & 48 & 2 & 2 \\
Cádiz, Spain & 24 & 2 & 2 \\
Palmones, Spain & 27 & 3 & 2 \\
Pria Gandarío, Spain & 33 & 6 & \\
Mira River, Portugal & 62 & & \\
US East Coast & & 3 & \\
Appledore Island, Maine & 31 & 2 & 2 \\
Adams Point, New Hampshire & 30 & & 2 \\
\hline
\end{tabular}


Appendix 1 (continued)

\begin{tabular}{|c|c|c|c|}
\hline Sites & Sample size & Richness & Adjusted richness \\
\hline Manomet, Massachusetts & 33 & 2 & 2 \\
\hline Weekapaug, Rhode Island & 42 & 1 & 1 \\
\hline Stonington, Connecticut & 55 & 1 & 1 \\
\hline Barn Island Marsh, Connecticut & 22 & 0 & 0 \\
\hline Rocky Neck and Saybrook, Connecticut & 25 & 1 & 1 \\
\hline Ocean City, Maryland & 18 & 1 & 1 \\
\hline \multicolumn{4}{|l|}{ Hemigrapsus sanguineus } \\
\hline \multicolumn{4}{|l|}{ Asia } \\
\hline Oshoro, SW Hokkaido & 20 & 2 & 2 \\
\hline Usujiri, SE Hokkaido & 61 & 3 & 2 \\
\hline Asamushi, North Honshu & 20 & 1 & 1 \\
\hline Otsuchi, North Honshu & 20 & 1 & 1 \\
\hline Gyotoku, Tokyo Bay & 16 & 1 & 1 \\
\hline Misake, Sagami Bay & 26 & 2 & 2 \\
\hline Tateyama, Chiba Peninsula & 18 & 1 & 1 \\
\hline \multicolumn{4}{|l|}{ US East Coast } \\
\hline Appledore Island, Maine & 19 & 0 & 0 \\
\hline Gloucester, Massachusetts & 15 & 0 & 0 \\
\hline Edgartown, Massachusetts & 22 & 0 & 0 \\
\hline Weekapaug, Rhode Island & 30 & 0 & 0 \\
\hline Lewes, Delaware & 18 & 1 & 1 \\
\hline Ocean City, Maryland & 22 & 1 & 1 \\
\hline
\end{tabular}

Editorial responsibility: Hans Heinrich Janssen, Oldendorf/Luhe, Germany
Submitted: February 4, 2009; Accepted: July 16, 2009 Proofs received from author(s): October 21, 2009 